DOI:

\title{
GENERAL CHARACTER OF THE IMAGE OF THE "DOG" IN THE FOLK SAYINGS OF THE "SLAVIC CULTURAL ZONE" VOLGA AND CARPATHIAN REGIONS (TURKIC INFLUENCE IN THE IMAGE OF THE "DOG" IN PHRASEOLOGY)
}

\author{
Imre Pacsai \\ Habilitated doctor of Philological Sciences, Professor \\ College of Nyíregyháza \\ (Nyíregyháza, Hungary) \\ e-mail: drpacsai@gmai.com
}

\begin{abstract}
Studying the linguistic works of the end of the $\mathrm{XX}^{\text {th }}$ century and the works of the XXI ${ }^{\text {st }}$ century, we observed that the scientific investigation of the national mentality that is reflecting in the language and the character of the upward tendency in the linguistic. This phenomenon connected with the revidial of Wilhelm Humboldt's theory and his school. The mentioned problem strictly connected with the increasing interest to the phraseology which is represented by the works of European and American linguists. In the phraseologic works we observed the investigation of the zoonym «dog» which figures in the phraseology of every language. The new character of our comparative study is the scientific investigation of phraseology of the Russian cultural zone established by Trubetzkoy and the Karpathian zone.

This comparative study is based on the similarity of the phraseology of Russian, Turkish, Finnougric and Hungarian people. This comparison hasn't been done in spite of the similarity of methaphoric picture of many idioms used in the mentioned language. Comparing the role and description of dog many paralel structures appeared and the common elements of national mentality. The similar character of the description of the «dog» in the methaphoric pictures in the compared zones reflect the common Turkish influence. This influence is proved by many Turkish structures which appear in the semantic borrowings of the mentioned cultural zones.
\end{abstract}

Keywords: the scientific investigation, zoonym «dog», the national mentality, comparativ analysis, similarity of the idiomes, increasing interest to the phraseology, semantic borrowings, Turkish influence 


\title{
ОБЩИЙ ХАРАКТЕР ОБРАЗА «СОБАКИ» В НАРОДНЫХ ИЗРЕЧЕНИЯХ «СЛАВЯНСКОЙ КУЛЬТУРНОЙ ЗОНЫ» РЕГИОНОВ ПОВОЛЖЬЯ И КАРПАТ \\ (ТЮРКСКОЕ ВЛИЯНИЕ В ИЗОБРАЖЕНИИ ОБРАЗА «СОБАКИ» ВО ФРАЗЕОЛОГИИ)
}

\author{
Имре Пачаи \\ Хабилитированный доктор филологических наук, профессор \\ Ньиредьхазская высшая школа \\ (Ньиредьхаза, Венгрия) \\ e-mail: drpacsai@gmai.com
}

\begin{abstract}
Аннотация. В лингвистических работах конца 20-го века наблюдается повышенный интерес к вопросам национальной ментальности и изображения языковой картины мира. Данное явление отражает возобновление интереса к деятельности В. ф. Гумбольдта и его школы, в частности, - к углубленному изучению проблем фразеологии, что подтверждается работами европейских и американских лингвистов.

При изучениии фразеологических работ мы могли установить, что изображение зоонима «собака» часто явлется темой фразеологического исследования в разных языках. Популярность этой темы объясняется тем, что образ собаки используется во фразеологии разных языков. Новизна нашей работы заключается в том, что мы выбрали темой сопоставление фразеологии «славянской культурной зоны» и региона Карпат с точки зрения использования зоонима «собака», в которых обнаружились сходные мотивы ментальности. В основе нашего сопоставления лежат культурные контакты, тщательно изученные Н. С. Трубецким (1927). Тюркское влияние в изображении концепта «собака» наблюдается в народных изречениях упомянутого региона, что потверждается многими параллельными структурами-кальками, отражающими интенсивные и длительные контакты.
\end{abstract}

Ключевые слов: зооним «собака», народные изречения, фразеология, метафорическая картина, национальная ментальность, языки «культурной зоны», сопоставительный анализ, языковая картина мира

\section{ВВЕДЕНИЕ}

В настоящей статье рассматриваются фразеологические единицы и пословицы, изображающие образ «собака» в двух ареалах, так как при нашем сопоставительном исследовании обнаружились общие мотивы в составе народных изречений. При изучении лингвистических работ конца 20-го века наблюдается повышенный интерес к вопросам национальной ментальности и характера изображения языковой картины мира, что отражает теория В. ф. Гумбольдта и достижения его школы. Углубленное изучение фразеологии тоже связано с упомянутой тенденцией, о чем свидетельствуют работы О. Б. Ткаченко, В. Н. Телии, В. М. Мокиенко и других исследователей.

Новизна нашей работы заключается в выборе изучаемых регионов. При изучении литературы, занимающейся изображением животных во фразеологии, мы убедились в актуальности этой темы. Заслуживает пристального внимания, что в сопоставительных работах, изучающих образ «собаки» во фразеологии, руские фразеологические единицы были сопоставлены с немецкими (S. V. Burionkova), английскими (N. V. Ivushkina), китайскими (Wang-Minji) оборотами, но фразеология региона «славянской культурной зоны не привлекала внимания исследователей. 
Эта проблема интересна тем, что в работах О Туранском элементе в русской культуре (1925), Верхи и низы русской культуры (1927). Н. С. Трубецкого явно доказана интенсивная связь между русскими, тюркскими и финно-угорскими народами, живущими в Волжском бассейне. Н С. Трубецкой указал и на то, что русская народная культура Поволжья формировлась под влиянием интенсивных контактов с Востоком. Он подчеркивал, что русская культура этого региона ближе по своим характерным чертам к культуре тюркских и финно-угорских народов, чем культуре западных славян. Позицию Н. С. Трубецкого подтверждают и исследования известного чешского этнографа К. Хоралека (1962), указывающего на причину расхождений между русским и западнославянским фольклором. Выводы Трубецкого подтверждаются и результатами нашего исследования, так как при изучении фразеологии и фольклора «русской культурной зоны» (Pacsai 2002) обнаружились многие параллельные мотивы в изученных языках.

Выбором темы исследования сопоставление фразеологии «русской культурной зоны» Повольжья с фразеологией региона Карпат с точки зрения изображения зоонима «собака» в народных изречениях, мы делаем шаг к отмене белого пятна в лингвистике и культурологии. Данное сопоставление не отражено в изученных нами лингвистических работах. Это объясняется малоизвестным характером теории Н. С. Трубецкого (1927) об евразийских культурных контактах и мнения Н. А. Баскакова (1979) о необходимости сопоставительного исследования русской и тюркской фразеологий. С точки зрения ареальной лингвистики изучение фразеологии Карпатского бассейна тоже может расширить круг лингвокультурологических знаний. Венгерская фразеология известна немногим исследователям, поэтому сопоставительный анализ является нелегкой задачей.

При изучении народных изречений в языках «русской культурной зоны», установленной Н. С. Трубецким (1927) и региона Карпат мы обнаружили параллельные фразеологические единицы и пословицы в русском, тюркских и финно-угорских языках. Обнаруженные нами параллельные ФЕ мотвировали сопоставление зоонима «собака» в народных изречениях упомянутых культурных регионов. По нашему мнению, возникновение параллельных структур связано с общим тюркским влиянием в данных регионах. Для этимологического анализа важным источником служили параллельные народные изречения, так как тюркское влияние на венгерскую культуру и на культуру «русской культурной зоны» Поволжья является доказанным фактом.

\section{ОБЗОР ЛИТЕРАТУРЫ}

Многие работы, изучающие образ собаки во фразеологии в наши дни, доказывают повышенный интерес к этой теме. По мнению исследователей, изучение зоонима «собака» интересно с точки зрения лингвокультурологии, так как этот зооним часто присутствует во фразеологии разных народов. При изучении компаративных работ по фразеологии выделилась общая концепция исследователей. Они поставили целью представить общечеловеческое отношение к собаке по фразеологизмам в сопосталенных языках. По нашему мнению, сопоставление фразеологии народов, обладающих не сходными чертами национальной ментальности, не может довольно четко выделить особенности изображения концепта «собака» в русской фразеологии.

Ознакомление с компаративными работами, изучающими образа собаки в упомянутых выше языках, мотивировали выбор нашей темы и аспекта сопоставительной работы. По достижениям нашей более ранней работы (Расsаi 2002), раскрывшей 
параллельные народные изречения в языках русской культурной зоны, мы предполагали общий характер изображения собаки в упомянутом регионе. Венгерские народные изречения и словацкие эквиваленты служили ориентиром в данной работе, так как в нашей предшествующей работе мы обнаружили сходные элементы некоторых ФЕ. Мотивировали нашу работу положение Н. А. Баскакова, изложенное в книге Русские фамилии тюркского происхождения (1979) о необходимости сопоставительного изучения фразеологических единиц в русском и в тюрских языках, и работа О. Б. Ткаченко Сопоставительноисторическая фразеология слаянских и финно-угорских языков (1979).

Мы изучаем характер изображения концепта «собака» во фразеологии «русской культурной зоны» Поволжья и региона Карпат, так как мы обнаружили сходство между многими элементами фольклора, фразеологии этих регионов. Культурные и языковые контакты представляют причинные связи упомянутых соотношений, которым уделялось особое внимание в работах Н. С. Трубецкого. При сопоставительном исследовании народных изречений выделились соответствующие друг другу $Ф Е$, использующие сходные метафорические картины, отражающие роль культурных и языковых контактов, действующих в изученных нами ареалах.

Опорой для нашей сопоставительной работы послужила работа Религиозные верования восточнославянских народов XIX - начала XX в. С. А Токарева (1957). В главе „Поверья о животных” рассматриваются верования, связанные и с собакой. С точки зрения нашего исследования, он делает важное замечание: „Что касается лошади и собаки, двух главных и верных помощников человека среди животных, то роль их в обрядах и верованиях восточных славян еще никем серьезно не исследована. (Tokarev 1957, 56) Книга С. А Токарева дает важные сведения о представлениях и верованиях русского народа о собаке, которые чрезвычайно важны для исследования с точки зрения лингвокультурологии. В книге Лингвокультурология. Теория и методы (1997) профессора В. В. Воробьёва рассматриваются основные признаки этой дисциплины. Он подчеркивает следующие характерные черты этого направления лингвистики: „Лингвокультурологическое исследование соответствует общей тенденции современной лингвистики - переходу от лингвистики „имманентной”, структурной к лингвистике антропологической, рассматривающей духовно-практическую деятельность.” (Vorobev 1997, 6)

В этнографическом лексиконе Magyar néprajzi lexikon (1977-1982) и в работе Magyar mythológia (1854) известного венгерского этнографа Арнолда Ипойи (Ipolyi Arnold) представлены древние верования и суеверия венгров, связанные с образом собаки. Упомянутые работы также полезны в компаративном исследовании, так как отражают характер данного элемента венгерского народного менталитета.

Фразеология, по мнению исследователей, является важной категорией национального языка, в ней отражается характер национального менталитета. В работе В. Н. Телии Русская фразеология (1996) изложены основные задачи фразеологии. По мнению ученого, формы сознания, выступающие во фразеологических единицах, отображают ментальность человека. При определении понятия фразеологии В. Н. Телия указывет на связь фразеологии и национального менталитета: „Фразеологический состав языка - это зеркало, в котором лингвокультурная общность идентифицирует свое национальное самосознание.” (Telia 1996, 9)

При изучении данной проблемы мы польззовались богатыми источниками русской, тюркской и финно-угорской фразеологий изученных регионов. Источникими венгерской и словацкой фразеологий, типичных представителей региона культурной зоны Карпатского 
бассейна, также служили работы выдающихся этнографов, что содействовало углубленному анализу многосторонних вопросов.

\section{РЕЗУЛЬТАТЫ И ДИСКУССИЯ}

При изучении оборотов с концептом «собака» в народных изречениях изучаемых регионов выделился общий элемент национальной ментальности разных народов, живущих в русской культурной зоне Поволжья и в бассейне Карпат. Заслуживает пристального внимания точка зрения, что образ собаки во фразеологии изучаемых ареалов наделен отрицательными чертами. Русские народные изречения отображают отрицательное оценочное суждение о собаке, о чем свидетельствуют пословицы, поговорки и другие устойчивые элементы языка: Собака бела, собака черна, а дух один” (РПП 289); „Собаке собачья смерть.” (РПП 290); „Собачья дружба до первой кости.” (РПП 290); „Собаке собачий и кус.” (РПП 290); „Собаку мани, а палку держи” (РПП 289); „Собака хвастлива была, так и волки съели” (РПП 289); „Собака и на владыку лает” (Д ІІ/358).

Русские пословицы, в которых наблюдается метафорическая картина с образом собаки указывают на отрицатальные черты данного животного в русском народном сознании. С. А. Токарев (1957) во главе своей книги „Поверья о животных” освещает корни этих представлений: „Есть представление, что собака может видеть нечистую силу, незримую для человека. С другой стороны, чёрт охотно принимает вид черной собаки, в собаку превращаются и колдун, и ведьма. Христианский отпечаток носит представление о собаке, как о нечистом животном. Ее нельзя допускать в церковь, особенно в алтарь. Пища делается непригодной для человека, если собака даже только понюхает еe." (Tokarev 1957, 57)

По тюркским традициям, «собака» тоже является нечистым животным, которое оскверняет мечеть. Турецкая пословица „еceli gelen köpek cami duvarına (alusuna) siyer” (ТуРС 259) выражает данное отношение к собаке, которой суждено околеть, мочится у стены мечети'. Эта пословица посредством метафорической картины образно выражает смысл: «человек, идущий навстречу своей гибели».

В работах Magyar néprajzi lexikon и Magyar mythhológia А. Ипойи (1854) представлены сходные мотивы верований и суеверия о собаке. По венгерским верованиям собака тоже является нечистым животным. Венгерская поговорка „Ki kutya a templomból!” (ME 483) 'вон, собака из церкви' отражает сходную мысль, которую мы наблюдали в турецкой пословице и в трактовке С. А. Токарева. По венгерским верованиям, ведьма может превращаться в собаку и наводить порчу на людей. Упомянутое суеверие, связанное с собакой, сохранлось в протоколах тяжбы по случаю обвинения в колдовстве, составленных в средние века в Венгрии. В этих документах говорится о том, что ведьма появилась в образе собаки и мучила людей. Она наводила порчу и на животных, в первую очередь на коров, в образе черной собаки. Эта собака говорила человеческим голосом и, получив рану, опять превращалась в человека. По демонологии церкви черная собака является воплощением черта.

В средние века тело казненного преступника разрубляли на части и бросали собакам, чтобы он стал вечным рабом ада. По традициям степных народов, жителей Восточной Европы и венгров, собачье мясо не пригодно для человеческой пищи. Эта традиция сохранилась у венгров до наших дней.

С точки зрения культурных традиций заслуживает пристального внимания пословица, зафиксированная в сборнике В. И. Даля: „Собаку грешно кликать человеческим именем” 
(Д II/358). Традиция, упомянутая В. И. Далем, наблюдается и в Бассейне Карпат, так как коней, коров, волов допускалось называть человеческим именем, а собак - нет. Словарь русского языка С. И. Ожегова (1987) тоже отражает негативную оценку образа собаки, что подтверждается семантическим толкованием лексических синонимических единиц «пёс, собака»: собака: 1) домашнее животное из семьи хищных млекопитающих; 2) перен. О злом, грубом человеке (разгов)'. (Ozhegov 1987, 642) пёс: 1) то же, что собака, а также самец-собака, кобель. Пёс его знает (то же, что черт его знает; готовом на любые низкие поступки, дела (презр., бран) (Ozhegov 1987, 443)

Семантика русских слов «собака, пёс» свидетельствует об укоренении верований и национального менталитета, упомянутых С. А. Токаревым (1967) на уровне лексики. При изучении лексики тюркских языков наблюдается сходная семантика слова, обозначающего денотат «собака». Отрицательный характер собаки, которая по верованиям степных народов является живым образом беса и нечистых сил, отражается во многих тюркских фразеологических единицах. Этот элемент менталитета наблюдается и в семантике слова, со значением «собака»:

Башкирское эт (БРС 805) '1) собака, пёс; 2) 'злой, скверный, вредный';

Чувашское слово йытӑ (ЧРС 132) '1) собака, пёс; 2) 'подлец'

Татарское этлек (ТаРС 686) 'присущие собаке нравы, подлость, свинство'

В турецком языке, подобно русскому, тоже используются синонимы k̈̈pek и it со значением «собака», которые одинаково отражают негативное суждение о собаке:

Турецкое it (ТуРС 482) '1) собака, пес; 2) негодяй, подлец',

Турецкое köpek (ТуРС 566) '1) собака, пес; 2) 'подлец, негодяй'

Узбекское ит (УзРС 186) 1) 'собака, пес'; 2) негодяй, дурный человек',

Этот семантический признак наблюдается и в финно-угорских языках Волжского бассейна:

Мордовское киска (ЭРС 268) 1) собака; 2) перен. негодяй

Марийский оборот пийлык (МаРС 249) 'подлость, грубось', связанное со словом пий (МаРС 249) 'собака, пес' тоже выражает отрицательное отношение к собаке.

С точки зрения ареального исследования заслуживает пристального внимания, что в венгерском языке денотат «собака» обозначается тоже синонимами, подобными турецким и

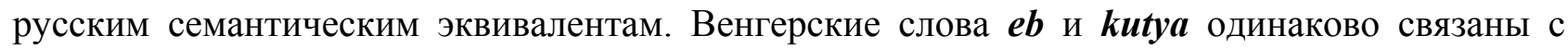
отрицательными качествами человека, о чем свидетельствуют народные изречения ebül gyült pénz (BPC I /421) 'бешеные деньги'; Kutyából nem lesz szalonna (BPC 1/ 1466) 'из хама не бывает пана (букв.: из собаки не будет сала'.

Венгерские ботанические нзвания ядовитых растений ebszölö 'паслен (Solanum) / букв.: собачий виноград) и kutyabenge 'крушина (Rhamnus) / букв.: собачье бенге' тоже отражают негативный характер этих сдов.

\section{Фразеологические единицы тюркских языков}

Башкирские обороты эт әзәм (БРС 805) 'скверный человек (букв.: собачий человек); эт ялкауы (БРС 805) 'слишком ленивый (букв.: ленивый как собака).

Чувашские фразеологические единицы йытӑ с̧иесшӗ! (ЧРС 132) 'чтобы (ему) сгинуть! (букв.: пёс бы его съел!)'; йытӑлан (ЧРС 132) 'наглеть, терять стыд и совесть; нахальничать'; йыmăлла (ЧРС 132) '1) собачий; как у собаки; йытӑлла пурнӑс̧ӗ (ЧРС 132) 'собачья жизнь; 2) нахальный, наглый, бессовестный'; йытӑлла хӑтланин (ЧРС 132) 'наглый поступок' подтверждают отрицательную оценку собаки, соответствуют семантике лексической единицы йытӑ. 
Татарские выражения этлек өшлэү (ТаРС 687) 'сделать подлость'; эт этлеген итмәсә, өче куб (ТаРС 687) 'от плохого - ожидай худого (букв если собака не поступает пособачьему, то у нее живот пучит)'; эm aвblз (ТаРС 686) 'сквернослов, болтун, брехун (букв. собачьи уста)' изображают негативные черты собаки.

Турецкие обороты it canli (ТуРC 482) 'бран. собачья душа'; it(in) götüne sokmak (ТуРC 482) 'осрамить, опозорить'; ite bulaşmaktansa çallyl dolaşmak yeğdir (ТуРС 482) 'чем пачкаться о собаку, лучше отойти в кустарник'; it değmekle (işemekle) deniz pis olmaz (ТуРС 482) 'от прикосновения (осквернения) собакой море не опоганится'; it derisinen post olmaz (ТуРС 482) 'из собачьей шкуры овчины не получится'. Пословица iti an çomăgi hazirla (ТуРС 482) 'если собака с тобой - держи палку' предупреждает человека, что он должен быть бдительным, если вынужден иметь дело с плохими, нечестными людьми. Оборот it iti yemez (ТуРС 482) 'собака собаку не ест' говорит о том, что негодяи защищают друг друга.

Фразеологические единицы со словом köpek также отражают негативное суждение турецкого человека. В турецкой пословице „, k̈pekle yatan pire ile kalkar' (ТуРС 566) 'с собакой ляжешь - с блохами встанешь' зооним «собака» символизирует нечестного человека, который может испортить и честного. Азербайджанская пословица „Itlo yatan bitlo qalxar" (As 14) 'кто с собакой ляжет, с блохами встанет' является эквивалентом турецкого народного изречения.

Об отрицательном характере образа собаки в туркменской фразеологии говорят обороты „,иm масгарасы” (ТуркРС 361) 'позор (букв.: собачий позор)'; „ит өлен ерде” (ТуркРС 361) 'у черта на кулички (букв.: там, где собака сдохла)'; „ызына ит салмак” „,ызына ит салмак” (ТуркРС 361) 'гнать с позором (букв.: натравить вслед собаку)'; „итден aльл, ите бермек” (ТуркРС 361) 'ругать, бранить, пробирать кого-л.'; „ит гөзи түссе билмез” (ТуркРС 361) 'собачьи глаза дыма не чуют'; „ит аягыны иен яль” (ТуркРС 361) 'любитель гулять, бродить (букв.: словно собачью ногу съел)';

В киргизском народном сознании образ собаки тоже обладает отрицательными чертами, о чем свидетельствуют следующие народные изречения: „ит аягыныбир күн бок жебесе, башы ооруйт" (КиРС 304) 'о пакостнике (букв.: если собака день не поест дерьма, у нее голова болит)'; „үйҮ жакин иттин куйругу узун” (КиРС 304) 'дома каждый храбрый (букв.: у собаки, дом которой близко, хвост длинный)'; „ит терисинен жек көрөм” (КиРС 304) 'ненавижу всеми фибрами души (букв.: отношусь хуже, чем к собачьей шкуре)'; „иm өлүк кыл (КиРС 305) 'осрамиь, опозорить'; „иттин баласы” (КиРС 304) 'сукин сын'; „ит кубар киши” (КиРС 305) 'легкомысленный, непостоялый человек'; „иттин мурунан түшкөндөй” (КиРС 305) 'с цепи сорвался (букв.: как из собачьего носа вывалился)'; „ит чикир!" (КиРС 305) 'пусть собака пьет! (презрительно)';

Слово иm 'собака' и в узбекских народных изречениях символизирует отрицательные качества. Оборот ,ит эмган" (УзРС 186) 'сосавший собаку' в основном соответствует русской ФЕ «сукин сын», так как он является синонимом в синтаксическом плане. Пословица Иm иззгни тенгимас (Узб. Посл 134) 'собака не ценит уважения' выражает отрцательную черту собаки.

В русской народной речи образ собаки часто используется как средство ругательства. В произведениях русских народных писателей (П. И. Мельникова, П. Бажова, М. Шолохова, В. Шукшина, В. Белова) образ собаки использован в ругательствах, что отражает специфический элемент менталитета: „— Пес с ними!” (МЕЛ I/91); „, — Лопнет с досады nес смердящий! - в радостном восторге думал Марко Данилыч.” (МЕЛ II/140); „Нонича, сударыня, эти ямщики, пес их возьми, и с живого и с мертвого дерут, что захотят." (МЕЛ I/285); „Был в Полевой приказчик - Северьян Кондратьич. Из собак собака. Зверь.” 
(Баж 195); „- — А ты уж хлебнул, кобель старый!” (ШолТД III/ 136); „ - Ты, собачья кровь, на что свинец зашил в кнут?” (ШолДР 206); „- Собака ты! Каин!” (ШолДР 194); , — Ежели ты суиье вымя, затеешься тут курить” (ШолДР 55); „- Отец, сука, придержи, кинь топор!” (ШР 25); „- - Ну, сука! - просипел бригадир” (Бел 154);

Оборот сукин сын является типичным выражением русской народной речи, о чем свидетельствуют примеры, взятые из литературных произведений:

„- Ах, сукин сын! Ты за что же отца за бороду трепаешь?” (ШолДР 42); „— В плети их, сукиных сынов! ” (ШолДР 193); „- Т Только подойди рассукин ты сын!” (ШолТД IV/ 14); , — Да не былы вы там, сукины сыны!” (Шр 107); „, — Сукин ты сын, идол!” (ШЛ 10); , Ах, подлецы! Сукины дети!” (ШЛ 54); , - схватили там Севку Куприянова, самого негодника и сукинова сына!" (ЗК 144);

Типичный оборот русского народного ругательства сукин сын, использованный и в литературных произведениях, обладает пареллельными выражениями в изучаемом ареале. Образ собаки связан и с выражением брани в тюркских и финно-угорских языках: тат. эт баласы (ТаРС 687) 'сукин сын'; кирг. иттин баласы” (КиРС 304) 'сукин сын'.

Эквиваленты русской ФЕ сукин сын в турецком языке k̈̈рек ŏglu (ТуРС 566) 'бран.

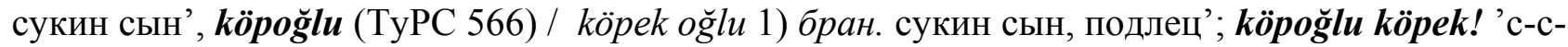
сукин сын!; 2) пройдоха; хитрец; негодяй' свидетельствуют о тюркском происхождении данного оборота. Семантика турецкого слова k̈̈pek (ТуРС 566) '1) собака, пёс; 2) бран. собака, подлец, негодяй' явно отражает отрицательный характер переносного значения данного слова. Об отрицательном характере лексемы «собака» говорит оборот k̈̈pekten edna saymak (ТуРС 566) 'считать кого хуже собаки'.

Турецкие слова k̈̈pekle(n)mek (ТуРС 566) 'унижаться, юлить как собака (перед кемл.), köpeklik (ТуРС 566) '1) пресмыкательство; унижение; 2) подлость, низость, гнусность' тоже свидетельтвуют об отношении к собаке в данном культурном обществе. Турецкие идеоматические обороты служат важными доказательствами тюркского влияния, так как в данном случае нельзя говорить о взаимных культурных контактах «русской культурной зоны».

О распространении данной формы брани в венгерском языке свидетельствуют ее варианты: Ebfi, kutyafi (ME 138) 'сукин сын' Ebanya terhe (ME 138) 'сукин сын (букв. сукино бремя)'; Ebszülte (ME 138) 'сукин сын (букв: его сука родила)'; Eb az anyja (ME 138) 'сукин сын (букв: его мать была сука)'. В работах, изучающих речевые традиции венгерского народа, упоминается о том, что в XVI-XVII-ом вв. людей строго наказывали за ругательство, и данные ФЕ с образом собаки считались самой грубой руганью.

Отрицательное суждение о собаке, упомянутое С. А. Токаревым (1957), подтверждается ругательством и изображением данного концепта в русских народных изречениях. По нашему предположению, в данном случае наблюдается сильное влияние тюркского менталитета и тюркской фразеологии. Наш знакомый, живущий в Средней Азии, говорил о том, что тамошние жители не любят людей, гуляющих с собакой. У казахов собаку не держат в доме, что отражает ментальность и традицию народа.

Об общих элементах фразеологии «русской культурной зоны» Поволжья и региона Карпат свидетельствуют многие структуры, отражающие в калькировании. „Собака бела, собака черна, а дух один” (РПП 289); узб. „ок ит, кара ит - барибир ит” (УзРС 186) 'белая собака, черная собака - все равно, собака'; венг. „Akár fehér, akár, fekete, elég, hogy kutya” (ONG 399/2037) 'белая собака, черная собака — все равно, собака'.

В финно-угорских языках «русской культурной зоны» зооним собака тоже символизирует отрицательные черты человека. Мордовские фразеологические единицы 
кискань седей (ФСМ 80) 'злой негодный (букв.: с собачьим сердцем)'; и пинень седи (ФСМ 143) 'по отношению к человеку: злой негодный (букв.: с собачьим сердцем)'; кискань сельме (ФСМ 80) / пинень сеельме (ФСМ 143) 'подлец, негодяй (букв.: с собачьи глаза)' менталитет упомянутой зоны.

Мокша мордовское слово piń $\varepsilon$ (JUH 123) 'собака, пес; злой человек' тоже свидетельствуют об отрицательном отношении к собаке. Образ собаки используется в

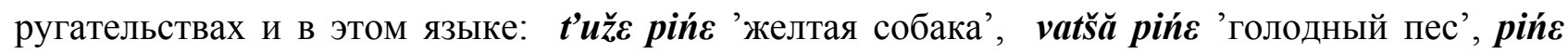

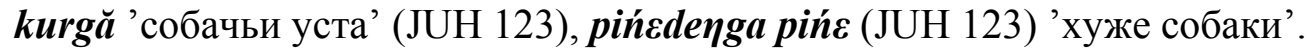

Пословицы удмуртского языка, использующие слово пуны (УдРС 122) 'собака, собачий' Пуны кадь лек (УдПП 96) 'злая как собака'; Пунысюл кадь. (УдПП 96) 'о назойливом человеке (букв.: как собачья кишка)'; Пунылэн утыэк улэмез уг луыл. (УдПП 96) 'не лаять собака не может (о злом человеке)'; Пунылы - пуны утялтон. (УдПП 96) 'собаке - собачье угощение'; Пуны быжзз косэ (УдПП 96) 'собака командует своим хвостом'; Пуны быжлэсь пуж уд лэсьты. (УдПП 96) 'из собачьего хвоста не сделаешь решета' отражают общий характер менталитета и суждения изученного региона.

При сопоставлении народных изречений языков в регионе Волги мы могли установить, что денотат «собака» изображается как нечистое животное и символизирует отрицательные характерные черты человека.

Следующий оборот свидетельствует о его распространении в русской культурной зоне: русск.: „Собаке - собачья смерть.” (РПП 290), татар.: „эткә эт үлме” (ТаРС 686) 'собаке - собачья смерть'; башкир.: „эткә эт үлеме” (БРС 805) 'то же', туркм.: „ите ит өлүми (ТуркРС 361) 'то же', эрза-мордовск.: кисканень кискань кулома (ЭРС 268) 'то же'.

Эквивалент изученного оборота используется и в венгерском языке: Ebhalál (ME 138) 'собачья смерть: „Ebhalállal vesszen el” (ME 138) 'пусть пропадет собачьей смертью'.

Общий характер изображения образа собаки свидетельствует о расространении специфического мотива культурных традиций в русской культурной зоне Поволжья, что соответствует положению Н. С. Трубецкого о роли языковых и культурных контактов, формирующих характер культуры данного региона.

Результаты нашего сопоставительного исследования подтверждают обоснованноость выводов Н. А. Баскакова о необходимости более углубленного исследования тюркских корней русских фразеологичских единиц:

„Не изучены тюркские заимствования в русском словообразовании (ср. например, тюркские модели в словообразовании некоторых так называемых парных слов) и фразеологии.” (Баскаков 1979, 5)

При изучении работ русских исследователей мы могли установить, что за прошедшие 40 лет в этой области лингвистики значительные исследования не появились. Результатам нашего исследования по этимологическому анализу русских народных изречений уделялось внимание, что подтверждается публикацией наших статей, вышедших в зарубежных международных журналах по лингвистике. Данные наших работ вошли и в историкоэтимологический словарь Русская фразеология (М. 2005), что доказывает новый характер направления нашего исследования.

Концепт «собака» в народных изречениях региона Карпат

При изучении сборников венгерских пословиц и поговорок (Margalits Ede 1896, O Nagy Gádor 1985) выделялись сотни народных изречений, что свидетельствувет о широком использовании образа собаки в венгерских народных изречениях, где используются

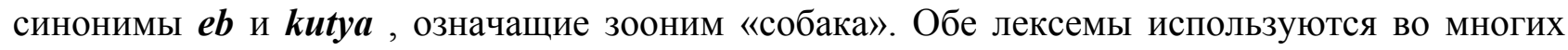
фразеоллогических единицах. В венгерской фразеологии концепт «собака» используется в 
отрицательном смысле, что подтверждается следующими примерами: Jó szokás nem ebszokás. (ME 136) 'хорошая привычка не волчья привычка'; Csak addig hisznek az ebnek, amíg látják. (ME 133) 'собаке верят, пока она перед глазами'; A kutya egy koncért a prédikációt is elhagyja. (ME480) 'собака за мосол покидает и проповедь'; Irigy mint a kutya. (ME 482) 'завистливый как собака'; Kutyaszokás a marakodás (ME 486) 'драться —это собачья привычка'; Kutyának kutya az embersége (ONG 409/ 2305) 'у собаки собачья честь'.

Упомянутое влияние тюркского менталитета обнаруживается и в венгерских ФЕ, имеющих тюркские эквиваленты: $\boldsymbol{E} \boldsymbol{b}$ a leleke (ONG 156/10) 'брань (букв. у него собачья душа)'; эт ж⿻ан (ТаРС 687) ' а) живучий, крепкий ; б) жестокий, бесчеловечный (букв.: собачья душа)'; Ebszáj (ME 138) 'сквернослов, болтун, брехун (букв. собачьи уста)' > Ne higgy az ebszájnak! (ME 138) 'не верь сквернослову, клеветам'; тат. эт авыз (ТаРС 687) 'сквернослов, болтун, брехун (букв. собачьи уста)'; kutya lakodalom (ME 489) / kutyalagzi (ME 486) 'всякий сброд; сборище (букв.: собачья свадьба); тат. эт туе (ТаРС 687) 'всякий сброд; сборище (букв.: собачья свадьба). Данное сходство подтверждает общий элемент менталитета в изученных нами языках.

Тюркские эквиваленты венгерской пословицы Nem megy ebnek szemébe a füst. (ONG 161/140) 'мерзавца трудно осрамить, он не стесняется (букв.: собаке дым не попадет в глаза)'свидетельствуют тат. эт кузе төтен белмес (ТаРС 577) 'мерзавцы не стесняются, не стыдятся (букв. собаке дым глаза не выест)'; ,эт күзе төтөн белмәс” (БРС 806) 'мерзавец не стесняется (букв. сглаза собаки дым не чуют), туркм. „ит гөзи түссе билмез” (ТуркРС 361) 'собачьи глаза дыма не чуют' говорят о тюркском происхождении венгерской пословицы.

При изучениии татарской, башкирской, туркменской и венгерской фразеологий обнаружились тождественные мотивы метафорической картины, что свидетельствует о культурных и языковых контактах. Образ собаки часто используется как в тюркской, так и венгерской фразеологии для изображения отрицательных характерных черт человека. Интенсивные тюркско-венгерские контакты возникли до завоевания долины Карпат, во время миграции венгерского народа в средние века. Печенеги, куманы, поселившиеся на территории Венгерского королевства также обогащали культурные традиции венгров.

В Карпатском бассейне венгры установили интенсивные контакты и со славянскими народами. Особенно сильными были контакты со словаками, живущими в северном регионе Карпатского бассейна. Об интенсивных контактах свидетельствует большое количество лексем, заимствованных из венгерского языка. О венгерском влиянии говорит ударение слов в словацком языке, которое отличается от других славянских языков. В словацком фольклоре используются типичные элементы венгерского фольклора, обладающие восточным характером. При изучении народных изречений региона Карпат выделились общие черты изображения собаки в пословицах и поговорках. Особенно много параллельных народных изречений с концептом «собака» обнаружилось в венгерском и словацком языках. Многие из них скалькированы. Примеры:

Венг.: Eb is venne húst a fogára, csak pénze volna. (ONG 159/92) 'если у собаки были бы деньги, купила бы мясо на них'; Aj pes by si mäsa kúpil, keby mal peniaze. (SLP 95);

Венг.: Kutyaugatás nem hallatszik az égbe. (ONG 412/2368) 'собачий лай не дойдет до небес'; словацк.: Psí hlas do neba nejde. (SL'P 234); Psie hlasi nejdú v nebesi. (SLPP 93); Венг.: Bocsásd a kutyát az asztal alá, felmászik az asztalra. (ONG 408/2277) 'пусти собаку под стол, она лезет на стол'; словацк.:Posad' psa pod stôl, vyjde ti na stôl. (SL'P 143); 
Венг.: Örizkedjél az alvó kutyától! (ONG 410/2327) 'берегись спящей собаки';. Ne higgy az alvó ebnek. (ONG 1601/136) 'не верь спящей собаке'; словацк.: Psovi, ked' spí - never. (SP 179); Венг.: Nehezen alkuszik meg két eb egy csonton (ONG 160/132) 'трудно поделиться двум собакам одной костью'; словацк.: Dva psi na jednom koštiali skoro sa porujú. (TVR 347) 'две собаки скоро поссорятся за одну кость';

Венг.: Leforrázták, mint a kutyát (ONG 406/ 2237) 'обварили как собаку'; Sompolyog, mint a leforrázott kutya. (ME 485); словацк.: Skuči ako obarený pes. (DOB 31) 'уплестился как обваренная собака'; венг.: Amelyik kutya sokat ugat, az nem harap. (ONG 408/2273) 'собака, которая много лает, не кусается'; словацк.: Pes, ktorý najviac breše, najmenej hryzie. (SL'P 233); Nekúše každý pes, ktorý šteká. (SLP 231); венг.: Ugat a félénk eb, de meg nem mar. (ME 137) 'боязливая собака много лает, но не кусается'; словацк.: Pes bojazlivý viac šteká, než kúše. (TVR 346); венг.: Hamarabb mar az eb, a ki nem ugat. (ME 136) 'молчаливая собака скорее укусит'; словацк.: Jedovitý pes malo šteká, ale mnoho kúše. (SLPP 135); Neboj sa psa čo brěse, ale toho, čo mlči. (TVR 347); венг.: Eb ebnek barátja (ONG 159/ 105) 'собака друг собаки'; словацк.: Pes psu brat. (TVR 347).

При изучении происхождения параллельных пословиц тюкркские эквиваленты служили доказательством при определении первоисточника, так как словаки не имели контактов с тюркскими народами. Восточные параллели словацких оборотов: словацк.: Pes psa žrat' nebude. (SLP 143); турец. it iti yemez (ТуPC 482) 'собака собаку не сожрет'; словацк.: Pes psa pozná. (SLP 143); турецк.: it iti bulur (ТуРC 482) 'собака собаку найдет'. венг.: На kutyával játszol, bot legyen a kezedben. (ONG 406/2250) 'если с собакой играешь держи палицу в руках';словацк.: . словацк.: So psom sah raj, a palicu v ruke drž. (DOB 52); So psom hraj a palicu v ruke maj. (SL'P 145. турецк.: iti an çomaği hazirla (ТуРC 482) 'говоря о собаке готовь палку'; русскк.: Собаку мани а палку держи. (РПП 290). венг.: Kutyának nöjjön a fü, ha kidöglenek a lovak. (ME 483) 'пусть собаке растет трава, когда вздохнут лошади'; словацк.. Nech psom trava raste, ked' kone podochnú. (DOB 57). Источником может быть узбекская половица Отнинг улими, итнинг байрами. (Узб Посл 132) 'смерть лошади - пир собаки'.

С точки зрения этимологического алализа заслуживает пристального внимания тождество метафорической картины венгерской пословицы „Kutyából nem lesz szalonna” (ONG 409/2300) 'плохие нравы трудно изменяются (букв.: из собаки не будет сала (не готовят сало)' и словацкого эквивалента „Nebude zo psa slanina” (DOB 9/37) ' 'плохие нравы трудно изменяются (букв.: из собаки не будет сало'.

Восточное происхождение венгерской пословицы „Kutyából nem lesz szalonna” подтверждается чувашской пословицей: „Йыта мӑнтӑр та, с̧име юрамасть” (АЧС т. 4 с. 302) 'пусть собака будет жирной, но ее мясо не едят'

Персидская пословица „Sag ke čâq škurme-aš nemi konand.” (ППП 134/ 738) 'пусть собака станет жирной - каурму (жареное мясо) не готовят из нее'

Персидская пословица по своей метафорической картине является эквивалентом венгерской. Ключевые слова пословиц szalonna 'сало' и каурма 'мелкие куски свинины, жареные на масле или на жире' являются сходной пищей, изготовленной из свинины, важной едой для крестьян зимой.

При сопоствлении словацкой пословицы Nebude zo psa slanina как с польским смысловым эквивалентом ,i w Pariz̈и nie zrobia z owsa riżu” (SWP 994), так и с немецкой пословицей „die Katze läßt die Mäusen nicht” (В-ГС II/252) и с русской „Из хама не бывает nана"(РПП 145) выделяется расхождение между метафорическими картинами пословиц, выражающих общую мысль. 
Венгерским пословицам Ebnek mondják, eb (meg) a farkának (ONG 157/ 105) 'собаке говорят, что собака скажет своему хвосту'; Ebnek mondják, eb mondja farkának, farka mondja: eb menjen. (ME 217) 'собаке говорят, что собака скажет своему хвосту, а хвост отвечает: пусть идет сама собака', по содержанию использованной метафорической картины соответствует словацкая пословица Rozkáž psovi, pes chvostovi a spav si sam (TVR 138).

В тюркских языках используются эквиваленты упомянутых пословиц: крымскотатарск.: ит итке, ит де - къуйругъына (АС 69) 'собака собаке - собака хвосту', башкир.: эт этке, эт койрокка (БРС 366) 'собака собаке - собака хвосту'; турецк.: it ite (buyurmuş) it de kuyruğuna (buyurmuş) 'собака приказала собаке, а та - своему хвосту' (ТурРС 482), которые соответствуют по содержанию и метафорической картине словацкой и венгерской пословицам.

Заслуживает пристального внимания сходство содержания и метафорической картины удмуртской пословицы Пуны быжзэ косэ (УдПП 96) 'собака командует своим хвостом', которое, несомненно, отражает влияние тюркских контактов, действующих в изученном волжском регионе.

Общее содержание выражается при помощи общей метафорической картины в следующих пословицах: венг. Vess az ebnek, nem ugat, mert ha nem vetsz, megharap (ONG 161/144) 'брось собаке - она не залает, если не бросишь - укусит'; Vess a kutyának, s mindjárt nem harap meg (ONG 411/2340) 'брось собаке, она тебя не укусит'; слов.Hod' psovi chleba, neuhryzne t'a. (SLP 134) 'брось собаке хлеба, она тебя не укусит'; Hod' psovi koštial', čertu hlaveň, aby mlčal. (SLP 134) 'брось собаке кость, чтобы она замолчала'.

В турецких поговорках it ăgzına bir kemik (ТурРС 482) 'бросить кость собаке', köpekin ağzına kemik atmak (ТурРC 482) 'подкупить кого-л. подарками (букв.: бросить кость собаке)' изображен тот же жизненный опыт народа. Злого человека можно подкупить подарками и избежать его злонамерения, о чем свидетельствуют источники словацких и венгерских народных изречений.

При изучении словацких народных изречений наблюдается общий характер изображения образа собаки. В словацких пословицах также отражены отрицательные характерные черты человека, что связано с укоренением восточныого элемента ментальности в результате венгерских культурных и языковых контактов.

Тождество метафорической картины - важное доказательство при этимологическом анализе параллельных народных изречений. Тюркские параллели венгерской пословицы „ $\boldsymbol{A}$ kutya ugat, a karaván halad." (ONG. 407) 'собака лает, караван идет' свидетелльствуют о тюркскском происхождении этого венгерского народного изречения: тур.: „it ürür, kervan yürür” (ТурРС 482);' собака лает, караван идет', уйгур.: „It kavajdō, karavan kätädō.” (Kúnos, 9) 'собака лает, караван идет'; узбек.: „ит хурар, карвон утар” (УзРС 185); 'собака лает, караван идет': туркм.: „ит үйрер, кервен гечер” (ТуркРС 361);'собака лает, караван шагает'; кирг.: „ит рøт - кербен жvрøт” (КиРС 376) 'собака лает, караван идет'

Параллелельная русская пословица „Собака лает, владыка едет.” (Д. І. 142) отличается от венгерского и от тюркских эквивалентов по элементу владыка метафорической картины, который используется вместо восточной реалии караван.

Представленные нами параллельные примеры для этомологического анализа представляют информацию о происхождении русской и венгерской пословиц. Равенства и неравенства метафорической картины доказывают, что венгерский эквивалент восходит не к русскому примеру, а к тюркским аналогам. 
Метафорические картины-кальки сопоставленных пословиц свидетельствуют об интенсивных культурных и языковых контактах, возникших между словацкими и венгерским народами за тысячилетие совместной жизни

\section{ЗАКЛЮЧЕНИЕ}

В настоящей статье были рассмотрены ФЕ с концептом «собака» в языках «русской культурной зоны» Поволжья и региона Карпат, что было мотивировано сходными признаками изображения этого зоонима в народных изречених в этих ареалах. Наш сопоставительный анализ зоонима «собака» подтверждает положение С. А. Токарева в аспекте фразеологии и освещает этимологические корни русских народных верований. При сопоставлении русских фразеологических единиц, связанных с концептом «собака», обнаружились параллельные народные изречения в русском, тюркских и финно-угорских языках. Сходство между метафорическими картинами народных изречений указывает на общие мотивы языковой картины мира, отражающей общий характер этнокультурной модели. Способ восприятия действительности и ее отображение в народных изречениях определяется характером национальной ментальности культурного и языкового коллектива. При изучении данных вопросов важным ориентиром служила работа В. В. Вробьёва (1997), в которой представлены достижения лингвокультурологии. Через сопоствление параллельных ФЕ, отражающих калькирования, освещались этимологические связи, раскрытие которых, по мнению В. М Мокиенко (2007), является важной, но трудной задачей фразеологии.

Результаты нашего исследования при изучении зоонима «собака» соответствуют выводам Н. С. Трубецкого о многосторонних контактах народов в «русской культурной зоне». Мы убедились и в обоснованном характере выводов Н. С. Баскакова, побудившего исследователей на изучение тюркских влияний в русских народных изречениях, что содействовало освещению этимологических корней многих русских народных изречений.

Параллельные фразеологические обороты и пословицы, изображающие зооним «собака» в регионе Карпатского бассейна, также свидетельствуют о тюркском влиянии в формировании национального менталитета. Здесь необходимо говорить о том, что наш сопоставительный анализ венгерских и тюркских народных изречений, по мнению венгерских тюркологов, являетсся новой работой, так как эти вопросы не рассмотрены должным образом в венгерской лингвистике. Изучение венгерских влияний в словацкой фразеологии тоже может раскрыть новые данные о языковых и культурных контактах.

Представленные нами обороты, поговорки и пословицы изученных языков свидетельствуют об общем характере этнокультурной метафоры, использованной в народных изречениях в упомянутых регионах. Метафорическая картина отражает как характер языковой картины мира, так и специфические черты национальной ментальности. Представленные нами народные изречения с образом «собака» свидетельствуют не только об общем характере изображения концепта, параллельные структуры-кальки говорят о культурных и языковых контактах в исследуемых нами регионах.

\section{LIST OF REFERENCES}

Balázs, Géza 2005. Magyar frazeológia. Ethnica VII. évfolyam, 1. szám 8-16. Baskakov, N. A.. 1979 Russkie familii turkskogo proischoždenia. Moskva

Burenkova, S. V. 2008. Zoomorfičeskie obrazy nemeckoj i russkoj frazeologii Čeljabinsk 
Horálek, K. 1962. Studie o slovanské lidové poezii. Praha. «SPN»

Ipolyi, Arnold 1854 Magyar Mythológia Budapest

Ivuskina, N. V. 2012. Koncept «sobaka»v anglijskom i russkom jazykah s lingvokulturologičeskoj

točki zrenia Tambov. «Gramota»

Kolesov, V. V. 1999. Žizn' proishodit ot slova. Sankt-Peterburg,

Karimova, R. H. 2005. Semantika zoonimov vo frazeologii nemeckogo i russkogo jazykov. Tambov. «Gramota»

Michajlova, J.. N. - Zhao. I. 2016. Kulturnye konnotacii zoonimov v russkoj i kitajskoj frazeologii

. Novosibirsk

Mokienko, V. M.,. 1999. V glub’ pogovorki. Sankt-Peterburg. MiM» «Paritet»

Mokienko, V. M., 2007. Zagadki russkoj frazeologii. «Avalon». Sankt-Peterburg

Moravcsik, Edith A. 2009. Partonomic structures in syntax. New Directions in Cognitive

Linguistics. Amsterdam / Philadelphia

Permjakov, G. L. 2001, Poslovicy i pogovorki narodov Vostoka Moskva «Labirint»

Telia, V. N. 1996. Russkaja frazeologia Moskva

Tkačenko, O. B. 1979. Sopostavitel'no-istoričeskaja frazeologia slavjanskich i finno-ugorskich jazykov. Kiev. «Naukova dumka»

Tokarev, S. A.. Religioznyje verovania vostočnoslavjaskich narodov XIX-načala XX v. Izdatl'stvo Akademii nauk SSSR. Moskva

Troubetzkoy, N. S. 1925 O turanskom elemente v russkoj kul'ture In: Vestnik moskovskogo universiteta Ser.. 9, № 6, 58-69. 1990.

Troubetzkoy, N. S. 1927. Verchi i nizy russkoj kultury. In: Vestnik moskovskogo universiteta ser.. 9, № 1, 87-98. 1991.

Vorobjov. V. V. 1997 Lingvokulturologia. Teoria i metody . «Izd. Rossijsk. univ. družby narodov»

Moskva

Wang-Minji 2015 Obraz «sobaki»v russkoj i kitajskoj jazykovych kartinach mira. Tambov

\section{Временное сокращение источников}

As $\quad$ Atlar sözü. Tartib və ön sözün müellifi. Baki, 2004.

DOB Dobšinský, P. 1991. Slovenské obyčaje, povery a čary. «Pramene» Bratislava,

JUH Juhász Jenő Moksa-mordvin szójegyzék. Akadémiai Kiadó, Budapest, 1961.

Kúnos Kúnos Ignácz Adalékok a jarkendi törökség ismeretéhez. Budapest, 1912

ME Margalits Ede. Magyar közmondások és közmondásszerü szólások.

Budapest, Akadémiai Kiadó. 1990

MFS Smiešková, E. 1974. Malý frazeologický slovník. Slovenské pedagogické nakladatel’stvo v Bratislave

MNSz Magyar-német szótár. Akadémiai Kiadó. Budapest.1972

ONG O. Nagy G. 1985. Magyar közmondások és szólások. «Gondolat» Budapest

SL'P Slovenské l'udové príslovia 1953. Slovenské. vyd. krásnej. literatur. Bratislava

TVR Tvrdý, P. 1931. Slovenský frazeologický slovník. Vydal Spolok Sv. Vojtecha, Trnava

AC Atlar sözleri ve ajytmlar. Simferopol, 2002.

AЧC Ašmaryn, N..I.: Slovar' čuvaskogo jazyka v 17 tomach. Kazaň-Čeboksary 1928-1950

Баж Bažov, P. Malachitovaja škatulka.Rasskazy. «Sovetsk. pisatel'», Moskva. 1947 
Бел V. Belov Povesti i rasskazy. «Hudožestv. literatura», Moskva, 1984

БРС Baškirsko-russkij slovar', Moskva, 1996. «Russkij jazyk»’

Д I/II Poslovicy russkogo naroda. Sbornik V. Dal'a v dvuch tomach. Moskva, 1984

ЗК Zalygin, S. Komissia «Molodaja gvardia» Moskva 1976.

КиРС Kirgizsko-russkij slovar’, Moskva, 1965. «Russkij jazyk»

MaPC Marijsko-russkij slovar'. Joškar-Ola, 1991.

МЕЛ Mel'nyikov, P. I. Na gorach. «Izd. Pravda». Moskva, 1988

Ожегов Ožegov, S. I. Slovar' russkogo jazyka-«Russkij jazyk» Moskva, 1987

Пачаи Pacsai, I.. 2002. Specifika russkoj kulturnoj zony v russkoj narodnoj reči i fol'klore.

Nyíregyháza «STÚDIUM»

ППП Korogli, H. K. 1961. Persidskie poslovicy i pogovorki. «Vostocnaja literatura». Moskva

РПП An'ikin, V. P. 1988. Russkie poslovicy i pogovorki. Hud. literatura. » Moskva,

PФ Birich. A,.,Mokienko, V. M., Stepanova, L. I.. Russkaja frazeologia.

«Astrel - AST - Luks». Moskva, 2005.

TaPC Tatarsko-russkij slova r', Moskva, 1966. «Russkij jazyk»

ТуркРC Turkmensko-russkij slovar'. 1968. Moskva «Sovetskaja enciklopedia».

TyPC Turecko-russkij slovar', Moskva,1977. «Russkij jazyk»

УдПП Udmurtskie poslovicy i pogovorki. Iževsk. 1978

УзРC Uzbeksko-russkij slova'r. Moskva,, 1959. «Sovetskaja enciklopedia»

ФСМ Frazeologiceskij slovar' mordovskich jazykov. Saransk. 1973

ЧPC Čuvašsko-russkij slovar’. Moskva, , 1977. «Russkij jazyk»

ШЛ V. Shukshin Lobanovy. «Molodaja gvardia», Moskva,1975

ШолДР М. Sholochov Donskie rasskazy. «Tavria». Simferopol', 1981

ШолТД М. Sholochov Tichij Don. Moskva, «Hud. literatura» 1962.

Шp V.Shukshin Besedy prijasnoj lune. Rasskazy. Moskva, 1974.

ШP V. Shukshin Rasskazy. "Hud. literatura», Moskva 1984

ЭPC Erzansko-russkij slovar'. Moskva, 1993. «Russkij jazyk »

\section{For citation:}

Pacsai, I. (2020) General character of the image of the "dog" in the folk sayings of the "slavic cultural zone" Volga and Carpathian regions (turkic influence in the image of the "dog" in phraseology). International Scientific-Pedagogical Organization of Philologists "WEST-EAST" (ISPOP). Scientific Journal WEST-EAST. Vol 3 N1 (March, 2020). pp. 11-16. doi:

\section{Для цитирования:}

Пачаи, И. (2020) Общий характер образа «собаки» в народных изречениях «славянской культурной зоны» регионов Поволжья и Карпат (тюркское влияние в изображении образа «собаки» во фразеологии) // International Scientific-Pedagogical Organization of Philologists "WEST-EAST" (ISPOP). Scientific Journal WEST-EAST. Vol 3N1 (March, 2020). C. 11-16. doi:

Information about the author: Imre Pacsai - Habilitated Doctor of Philological Sciences, Professor, speciality Hungarian, Russian and French languages, Nyíregyháza High School, (Hungary) e-mail: $\underline{\text { drpacsai@gmail.com }}$ 
Сведения об авторе: Имре Пачаи - хабилитированный доктор филологических наук, профессор, специалист венгерского, русского и французского языков, Ньи́редьха́зская Высшая школа (Венгрия)

e-mail: drpacsai@gmail.com

Manuscript received: 12/04/2019

Accepted for publication: $01 / 15 / 2020$

Рукопись получена: 12/04/2019

Принята к печати: 01/15/2020 